Saudi Journal of Biomedical Research

Abbreviated Key Title: Saudi J Biomed Res ISSN 2518-3214 (Print) |ISSN 2518-3222 (Online)

\title{
Measurement of Nineteen Chemical Elements in Thyroid Malignant Nodules and Thyroid Tissue Adjacent to Nodules using Neutron Activation Analysis and Inductively Coupled Plasma Atomic Emission Spectrometry
}

\author{
Vladimir Zaichick ${ }^{1 *}$ (ii)
}

${ }^{1}$ Radionuclide Diagnostics Department, Medical Radiological Research Centre, Russia

ORCID: 0000-0002-4286-4267

DOI: $10.36348 /$ sjbr.2022.v07i01.007

| Received: 11.12.2021 | Accepted: 24.01.2022 | Published: 29.01.2022

*Corresponding author: Professor, Dr. V. Zaichick

Radionuclide Diagnostics Department, Medical Radiological Research Centre, Russia

\section{Abstract}

Thyroid malignant nodules (TMNs) are the most common endocrine cancer and the fifth most frequently occurring type of malignancies. The etiology and pathogenesis of TMNs must be considered as multifactorial. The present study was performed to clarify the role of some chemical elements (ChEs) in the etiology of these thyroid disorders. Thyroid tissue levels of nineteen ChEs were prospectively evaluated in malignant tumor and tissue adjacent to tumor of 41 patients with TMNs. Measurements were performed using a combination of non-destructive and destructive methods: instrumental neutron activation analysis with high resolution spectrometry of short-lived radionuclides and inductively coupled plasma atomic emission spectrometry. Results of the study were additionally compared with previously obtained data for the same ChEs in "normal" thyroid tissue. It was observed that in malignant tissue the mass fractions of $\mathrm{Al}, \mathrm{B}, \mathrm{Ca}, \mathrm{Cl}, \mathrm{Cu}, \mathrm{K}$, $\mathrm{Mg}, \mathrm{Mn}, \mathrm{Na}, \mathrm{P}, \mathrm{S}$, and $\mathrm{Si}$ were 3.14, 4.64, 1.79, 2.26, 3.55, 1.57, 1.61, 1.57, 1.24, 2.45, 1.14, and 2.81 times, respecti vely, higher whereas mass fraction of I was 25.6 times lower than in the normal thyroid. In the "adjacent" group mean mass fractions of $\mathrm{Cl}$ and I were approximately 1.6 and 1.7 times, respectively, higher, while mean values of $\mathrm{Ba}, \mathrm{Ca}$ and $\mathrm{Sr}$ content were $55 \%, 45 \%$, and $70 \%$, respectively, lower than in the "normal" group. In tumor $\mathrm{Ca}, \mathrm{Cl}, \mathrm{Cu}, \mathrm{K}$, and $\mathrm{Sr}$ contents were approximately $2.8,1.4,1.8,1.7$, and 5.4 times, respectively, higher, while I content was 43 times lower than in "adjacent" group of tissue samples. It was concluded that thyroid tissue adjacent to malignant nodules kept the main function of thyroid gland, while malignantly transformed thyroid cells lost its capacity to accumulate I. It was supposed that the excessive accumulation of $\mathrm{Cl}$ and I by thyroid tissue probably precede the TMNs origination and development. It was also supposed that elevated levels of $\mathrm{Al}, \mathrm{B}, \mathrm{Ca}, \mathrm{Cl}, \mathrm{Cu}, \mathrm{K}, \mathrm{Mg}, \mathrm{Mn}, \mathrm{Na}, \mathrm{P}, \mathrm{S}$, and $\mathrm{Si}$, as well as drastically reduced level of me in cancerous tissue could possibly be explored for differential diagnosis of benign and malignant thyroid nodules.

Keywords: Chemical elements; Inductively coupled plasma atomic emission spectrometry; Neutron activation analysis; Thyroid; Thyroid malignant nodules.

Copyright ( $) 2022$ The Author(s): This is an open-access article distributed under the terms of the Creative Commons Attribution 4.0 International License (CC BY-NC 4.0) which permits unrestricted use, distribution, and reproduction in any medium for non-commercial use provided the original author and source are credited.

\section{INTRODUCTION}

Thyroid malignant nodules (TMNs) are the most common endocrine cancer and the fifth most frequently occurring type of malignancies [1-3]. The incidence of TMNs has increased worldwide over the past four decades. TMNs are divided into three main histological types: differentiated (papillary and follicular thyroid cancer), undifferentiated (poorly differentiated and anaplastic thyroid cancer, and medullary thyroid cancer, arising from $\mathrm{C}$ cells of thyroid [3]. For over 20th century, there was the dominant opinion that TMNs is the simple consequence of iodine deficiency [4]. However, it was found that TMNs is a frequent disease even in those countries and regions where the population is never exposed to iodine shortage. Moreover, it was shown that iodine excess has severe consequences on human health and associated with the presence of TMNs [5-8]. It was also demonstrated that besides the iodine deficiency and excess many other dietary, environmental, and occupational factors are associated with the TMNs incidence [9-11]. Among these factors a disturbance of evolutionary stable input of many chemical elements 
Vladimir Zaichick., Saudi J Biomed Res, Jan, 2022; 7(1): 45-56

(ChEs) in human body after industrial revolution plays a significant role in etiology of TMNs [12].

Besides iodine, many other ChEs have also essential physiological functions [13]. Essential or toxic (goitrogenic, mutagenic, carcinogenic) properties of ChEs depend on tissue-specific need or tolerance, respectively [13]. Excessive accumulation or an imbalance of the ChEs may disturb the cell functions and may result in cellular proliferation, degeneration, death, benign or malignant transformation [13-15].

In our previous studies the complex of in vivo and in vitro nuclear analytical and related methods was developed and used for the investigation of iodine and other ChEs contents in the normal and pathological thyroid [16-22]. Iodine level in the normal thyroid was investigated in relation to age, gender and some nonthyroidal diseases [23, 24]. After that, variations of many ChEs content with age in the thyroid of males and females were studied and age- and gender-dependence of some ChEs was observed [25-41]. Furthermore, a significant difference between some ChEs contents in colloid goiter and thyroid adenoma in comparison with normal thyroid was demonstrated [42-45].

To date, the etiology and pathogenesis of TMNs must be considered as multifactorial. The present study was performed to find out differences in ChEs contents between the group of cancerous tissues and tissue adjacent to tumor, as well as to clarify the role of some ChEs in the etiology of TMNs. Having this in mind, the aim of this exploratory study was to examine differences in the content of aluminum $(\mathrm{Al})$, boron $(\mathrm{B})$, barium $(\mathrm{Ba})$, calcium $(\mathrm{Ca})$, chlorine $(\mathrm{Cl})$, coper $(\mathrm{Cu})$, iron $(\mathrm{Fe})$, I, potassium $(\mathrm{K})$, lithium $(\mathrm{Li})$, magnesium $(\mathrm{Mg})$, manganese $(\mathrm{Mn})$, sodium $(\mathrm{Na})$, phosphorus $(\mathrm{P})$, sulfur $(\mathrm{S})$, silicon $(\mathrm{Si})$, strontium $(\mathrm{Sr})$, vanadium $(\mathrm{V})$, and zinc $(\mathrm{Zn})$ in nodular and adjacent to nodules tissues of thyroids with TMNs using a combination of nondestructive instrumental neutron activation analysis with high resolution spectrometry of short-lived radionuclides (INAA-SLR) and destructive method such as inductively coupled plasma atomic emission spectrometry (ICP-AES), and to compare the levels of these ChEs in two groups (nodular and thyroid tissue adjacent to nodules) of the cohort of TMNs samples. Moreover, for understanding a possible role of ChEs in etiology and pathogenesis of TMNs results of the study were compared with previously obtained data for the same ChEs in "normal" thyroid tissue [42-45].

\section{MATERIAL AND METHODS}

All patients with TMNs $(n=41$, mean age $\mathrm{M} \pm \mathrm{SD}$ was $46 \pm 15$ years, range 16-75) were hospitalized in the Head and Neck Department of the Medical Radiological Research Centre (MRRC), Obninsk.. Thick-needle puncture biopsy of suspicious nodules of the thyroid was performed for every patient, to permit morphological study of thyroid tissue at these sites and to estimate their trace element contents. In all cases the diagnosis has been confirmed by clinical and morphological results obtained during studies of biopsy and resected materials. Histological conclusions for malignant tumors were: 25 papillary adenocarcinomas, 8 follicular adenocarcinomas, 7 solid carcinomas, and 1 reticulosarcoma. Tissue samples of tumor and visually intact tissue adjacent to tumor were taken from resected materials.

"Normal" thyroids for the control group samples were removed at necropsy from 105 deceased (mean age $44 \pm 21$ years, range 2-87), who had died suddenly. The majority of deaths were due to trauma. A histological examination in the control group was used to control the age norm conformity, as well as to confirm the absence of micro-nodules and latent cancer.

All studies were approved by the Ethical Committees of MRRC. All the procedures performed in studies involving human participants were in accordance with the ethical standards of the institutional and/or national research committee and with the 1964 Helsinki declaration and its later amendments, or with comparable ethical standards. Informed consent was obtained from all individual participants included in the study.

All tissue samples obtained from tumors and visually intact tissue adjacent to tumors were divided into two portions using a titanium scalpel to prevent contamination by ChEs of stainless steel [46]. One was used for morphological study while the other was intended for ChEs analysis. After the samples intended for ChEs analysis were weighed, they were freeze-dried and homogenized [47]. The pounded samples weighing about $10 \mathrm{mg}$ (for biopsy) and $100 \mathrm{mg}$ (for resected materials) were used for $\mathrm{ChE}$ measurement by INAASLR. The content of $\mathrm{Ca}, \mathrm{Cl}, \mathrm{I}, \mathrm{K}, \mathrm{Mg}, \mathrm{Mn}$, and $\mathrm{Na}$ were determined by INAA-SLR using a horizontal channel equipped with the pneumatic rabbit system of the WWR-c research nuclear reactor (Branch of Karpov Institute, Obninsk). After non-destructive INAA-SLR investigation the thyroid samples were used for ICPAES. The samples were decomposed in autoclaves and aliquots of solutions were used to determine the $\mathrm{Al}, \mathrm{B}$, $\mathrm{Ba}, \mathrm{Ca}, \mathrm{Cu}, \mathrm{Fe}, \mathrm{K}, \mathrm{Li}, \mathrm{Mg}, \mathrm{Mn}, \mathrm{Na}, \mathrm{P}, \mathrm{S}, \mathrm{Si}, \mathrm{Sr}, \mathrm{V}$, and $\mathrm{Zn}$ mass fractions by ICP-AES using the Spectrometer ICAP-61 (Thermo Jarrell Ash, USA). Information detailing with the NAA-SLR and ICP-AES methods used and other details of the analysis were presented in our earlier publications concerning ChE contents in human thyroid [33, 34], prostate [48-52], and scalp hair [53].

To determine contents of the ChE by comparison with a known standard, biological synthetic standards (BSS) prepared from phenol-formaldehyde resins were used [54]. In addition to BSS, aliquots of commercial, chemically pure compounds were also 
Vladimir Zaichick., Saudi J Biomed Res, Jan, 2022; 7(1): 45-56

used as standards. Ten sub-samples of certified reference material (CRM) IAEA H-4 (animal muscle) and five sub-samples of CRM of the Institute of Nuclear Chemistry and Technology (INCT, Warszawa, Poland) INCT-SBF-4 Soya Bean Flour, INCT-TL-1 Tea Leaves, and INCT-MPH-2 Mixed Polish Herbs were treated and analyzed in the same conditions that thyroid samples to estimate the precision and accuracy of results

A dedicated computer program for INAA-SLR mode optimization was used [55]. All thyroid samples for ChEs analysis were prepared in duplicate and mean values of ChEs contents were used in final calculation. Mean values of $\mathrm{ChE}$ contents were used in final calculation for the $\mathrm{Ca}, \mathrm{K}, \mathrm{Mg}, \mathrm{Mn}$, and $\mathrm{Na}$ mass fractions measured by two methods. Using Microsoft Office Excel software, a summary of the statistics, including, arithmetic mean, standard deviation, standard error of mean, minimum and maximum values, median, percentiles with 0.025 and 0.975 levels was calculated for ChEs contents in malignant and adjacent to tumor tissue of thyroids with TMNs. Data for "normal" thyroid were taken from our previous publications [4245]. The difference in the results between three groups of samples ("normal", "tumor", and "adjacent") was evaluated by the parametric Student's $t$-test and nonparametric Wilcoxon-Mann-Whitney $U$-test.

\section{RESULTS AND DISCUSSION}

Table 1 presents certain statistical parameters (arithmetic mean, standard deviation, standard error of mean, minimal and maximal values, median, percentiles with 0.025 and 0.975 levels) of the $\mathrm{Al}, \mathrm{B}, \mathrm{Ba}, \mathrm{Ca}, \mathrm{Cl}$, $\mathrm{Cu}, \mathrm{Fe}, \mathrm{I}, \mathrm{K}, \mathrm{Li}, \mathrm{Mg}, \mathrm{Mn}, \mathrm{Na}, \mathrm{P}, \mathrm{S}, \mathrm{Si}, \mathrm{Sr}, \mathrm{V}$, and $\mathrm{Zn}$ mass fraction in "tumor" and "adjacent" groups of thyroid tissue samples.

The ratios of means and the comparison of mean values of $\mathrm{Al}, \mathrm{B}, \mathrm{Ba}, \mathrm{Ca}, \mathrm{Cl}, \mathrm{Cu}, \mathrm{Fe}, \mathrm{I}, \mathrm{K}, \mathrm{Li}, \mathrm{Mg}$, $\mathrm{Mn}, \mathrm{Na}, \mathrm{P}, \mathrm{S}, \mathrm{Si}, \mathrm{Sr}, \mathrm{V}$, and $\mathrm{Zn}$ mass fractions in pairs of sample groups such as "normal" and "tumor", "normal" and "adjacent", and also "adjacent" and "tumor" are presented in Table 2, 3, and 4, respectively.

Table-1: Some statistical parameters of Al, B, Ba, Ca, Cl, Cu, Fe, I, K, Li, Mg, Mn, Na, P, S, Si, Sr, V, and Zn mass fraction (mg/kg, dry mass basis) in thyroid cancer (tumor and "intact" thyroid tissue adjacent to tumor)

\begin{tabular}{|c|c|c|c|c|c|c|c|c|c|}
\hline Tissue & El & Mean & SD & SEM & Min & Max & Med & P 0.025 & P 0.975 \\
\hline Cancer & $\mathrm{Al}$ & 33.0 & 25.5 & 7.1 & 4.50 & 96.5 & 21.3 & 5.70 & 85.6 \\
\hline \multirow{18}{*}{ (tumor) } & $\mathrm{B}$ & 2.21 & 1.89 & 0.52 & 1.00 & 5.60 & 1.00 & 1.00 & 5.42 \\
\hline & $\mathrm{Ba}$ & 1.42 & 1.30 & 0.35 & 0.220 & 4.09 & 0.945 & 0.259 & 3.93 \\
\hline & $\mathrm{Ca}$ & 3013 & 2966 & 699 & 452 & 9768 & 1578 & 467 & 8938 \\
\hline & $\mathrm{Cl}$ & 7699 & 2900 & 703 & 4214 & 14761 & 7216 & 4240 & 13619 \\
\hline & $\mathrm{Cu}$ & 14.5 & 9.4 & 2.6 & 4.00 & 32.6 & 10.9 & 4.21 & 31.4 \\
\hline & $\mathrm{Fe}$ & 255 & 168 & 27 & 60.6 & 880 & 217 & 74.6 & 673 \\
\hline & I & 71.8 & 62.0 & 10.1 & 2.00 & 261 & 62.1 & 2.93 & 192 \\
\hline & $\mathrm{K}$ & 10054 & 4018 & 877 & 1660 & 18814 & 9204 & 4073 & 17559 \\
\hline & $\mathrm{Li}$ & 0.0314 & 0.0307 & 0.0090 & 0.0078 & 0.111 & 0.0182 & 0.0088 & 0.0995 \\
\hline & $\mathrm{Mg}$ & 478 & 194 & 42 & 130 & 933 & 467 & 166 & 881 \\
\hline & $\mathrm{Mn}$ & 2.01 & 1.34 & 0.29 & 0.100 & 5.95 & 1.61 & 0.250 & 5.23 \\
\hline & $\mathrm{Na}$ & 8576 & 2433 & 531 & 4083 & 14048 & 8107 & 4901 & 12925 \\
\hline & $\mathrm{P}$ & 10493 & 3238 & 866 & 5382 & 15403 & 9694 & 5767 & 15391 \\
\hline & $\mathrm{S}$ & 9448 & 1605 & 429 & 7139 & 12591 & 9422 & 7211 & 12204 \\
\hline & $\mathrm{Si}$ & 143 & 156 & 42 & 18.6 & 523 & 64.2 & 19.8 & 472 \\
\hline & $\mathrm{Sr}$ & 6.26 & 7.61 & 1.59 & 0.93 & 30.8 & 3.00 & 0.985 & 25.0 \\
\hline & $\mathrm{V}$ & 0.0904 & 0.0308 & 0.0100 & 0.0580 & 0.170 & 0.0870 & 0.0600 & 0.154 \\
\hline & $\mathrm{Zn}$ & 96.9 & 80.0 & 12.6 & 28.7 & 375 & 69.8 & 36.3 & 374 \\
\hline Cancer & $\mathrm{Al}$ & 19.4 & 11.1 & 5.6 & 7.10 & 32.9 & 18.9 & 7.66 & 32.2 \\
\hline (adjacent & $\mathrm{B}$ & 5.80 & 9.60 & 4.80 & 1.00 & 20.2 & 1.00 & 1.00 & 18.8 \\
\hline thyroid & $\mathrm{Ba}$ & 0.50 & 0.32 & 0.16 & 0.230 & 0.920 & 0.415 & 0.232 & 0.894 \\
\hline \multirow[t]{10}{*}{ tissue) } & $\mathrm{Ca}$ & 917 & 524 & 131 & 81.0 & 1909 & 726 & 204 & 1822 \\
\hline & $\mathrm{Cl}$ & 5339 & 2252 & 581 & 2526 & 11767 & 4922 & 2595 & 10201 \\
\hline & $\mathrm{Cu}$ & 8.08 & 3.15 & 1.58 & 4.90 & 12.1 & 7.65 & 5.01 & 11.9 \\
\hline & $\mathrm{Fe}$ & 256 & 133 & 26 & 109 & 752 & 254 & 112 & 591 \\
\hline & I & 3183 & 1673 & 301 & 563 & 8240 & 2982 & 853 & 7766 \\
\hline & $\mathrm{K}$ & 5847 & 2558 & 661 & 2097 & 13092 & 5429 & 2559 & 11220 \\
\hline & $\mathrm{Li}$ & 0.0210 & 0.0203 & 0.0100 & 0.0096 & 0.0514 & 0.0115 & 0.0097 & 0.0485 \\
\hline & $\mathrm{Mg}$ & 359 & 402 & 104 & 15.0 & 1412 & 247 & 15.0 & 1287 \\
\hline & $\mathrm{Mn}$ & 1.77 & 1.60 & 0.40 & 0.410 & 6.78 & 1.25 & 0.429 & 5.54 \\
\hline & $\mathrm{Na}$ & 7726 & 2519 & 630 & 3865 & 14373 & 7434 & 4250 & 13009 \\
\hline
\end{tabular}


Vladimir Zaichick., Saudi J Biomed Res, Jan, 2022; 7(1): 45-56

\begin{tabular}{|l|l|l|l|l|l|l|l|l|l|}
\hline Tissue & El & Mean & SD & SEM & Min & Max & Med & P 0.025 & P 0.975 \\
\hline & $\mathrm{P}$ & 9724 & 5592 & 2796 & 4023 & 15979 & 9446 & 4181 & 15738 \\
\hline & $\mathrm{S}$ & 9725 & 1999 & 999 & 6989 & 11323 & 10293 & 7176 & 11306 \\
\hline & $\mathrm{Si}$ & 77.3 & 56.2 & 28.1 & 28.8 & 135 & 72.7 & 28.8 & 134 \\
\hline & $\mathrm{Sr}$ & 1.16 & 0.29 & 0.14 & 0.830 & 1.40 & 1.20 & 0.843 & 1.40 \\
\hline & $\mathrm{V}$ & 0.082 & 0.026 & 0.013 & 0.0630 & 0.120 & 0.0725 & 0.0636 & 0.117 \\
\hline & Zn & 111 & 55 & 11 & 20.4 & 272 & 107 & 28.8 & 215 \\
\hline
\end{tabular}

El - element, M - arithmetic mean, SD - standard deviation, SEM - standard error of mean, Min - minimum value, Max - maximum value, Med - median, P 0.025 - percentile with 0.025 level, P 0.975 - percentile with 0.975 level.

As was shown before [33,34,48-53] good agreement of the $\mathrm{Al}, \mathrm{B}, \mathrm{Ba}, \mathrm{Br}, \mathrm{Ca}, \mathrm{Cl}, \mathrm{Cu}, \mathrm{Fe}, \mathrm{I}, \mathrm{K}$, $\mathrm{Mg}, \mathrm{Mn}, \mathrm{Na}, \mathrm{P}, \mathrm{S}, \mathrm{Sr}, \mathrm{V}$, and $\mathrm{Zn}$ mass fractions in CRM IAEA H-4, INCT-SBF-4, INCT-TL-1, and INCT-MPH2 samples determined by both INAA-SLR and ICPAES methods with the certified data of these CRMs indicates acceptable accuracy of the results obtained in the study of thyroid tissue samples presented in Tables $1-4$.
From Table 2, it is observed that in malignant tissue the mass fraction of $\mathrm{Al}, \mathrm{B}, \mathrm{Ca}, \mathrm{Cl}, \mathrm{Cu}, \mathrm{K}, \mathrm{Mg}$, $\mathrm{Mn}, \mathrm{Na}, \mathrm{P}, \mathrm{S}$, and $\mathrm{Si}$ are 3.14, 4.64, 1.79, 2.26, 3.55, $1.57,1.61,1.57,1.24,2.45,1.14$, and 2.81 times, respectively, higher whereas mass fraction of $\mathrm{I}$ is 25.6 times lower than in the normal thyroid. Thus, if we accept the ChEs contents in thyroid glands of the "normal" group as a norm, we have to conclude that with a malignant transformation the $\mathrm{Al}, \mathrm{B}, \mathrm{Ca}, \mathrm{Cl}, \mathrm{Cu}, \mathrm{I}$, $\mathrm{K}, \mathrm{Mg}, \mathrm{Mn}, \mathrm{Na}, \mathrm{P}, \mathrm{S}$, and $\mathrm{Si}$ contents in thyroid tissue significantly changed.

Table-2: Differences between mean values (M+SEM) of Al, B, Ba, Ca, Cl, Cu, Fe, I, K, Li, Mg, Mn, Na, P, S, Si, $\mathrm{Sr}, \mathrm{V}$, and $\mathrm{Zn}$ mass fraction ( $\mathrm{mg} / \mathrm{kg}$, dry mass basis) in normal thyroid and thyroid cancer (tumor)

\begin{tabular}{|c|c|c|c|c|c|}
\hline \multirow[t]{2}{*}{ El } & \multicolumn{4}{|l|}{ Thyroid tissue } & \multirow{2}{*}{$\begin{array}{l}\text { Ratio } \\
\text { Tumor/Normal }\end{array}$} \\
\hline & $\begin{array}{l}\text { Normal } \\
\text { thyroid }\end{array}$ & $\begin{array}{l}\text { Cancer } \\
\text { (tumor) }\end{array}$ & $\begin{array}{l}\text { Student's t-test } \\
p \leq\end{array}$ & $\begin{array}{l}\text { U-test } \\
p\end{array}$ & \\
\hline $\mathrm{Al}$ & $10.5 \pm 1.8$ & $33.0 \pm 7.1$ & 0.0083 & $\leq 0.01$ & 3.14 \\
\hline $\mathrm{B}$ & $0.476 \pm 0.058$ & $2.21 \pm 0.52$ & 0.0062 & $\leq 0.01$ & 4.64 \\
\hline $\mathrm{Ba}$ & $1.12 \pm 0.15$ & $1.42 \pm 0.35$ & 0.446 & $>0.05$ & 1.27 \\
\hline $\mathrm{Ca}$ & $1682 \pm 106$ & $3013 \pm 699$ & 0.076 & $\leq 0.05$ & 1.79 \\
\hline $\mathrm{Cl}$ & $3400 \pm 174$ & $7699 \pm 703$ & 0.000013 & $\leq 0.01$ & 2.26 \\
\hline $\mathrm{Cu}$ & $4.08 \pm 0.14$ & $14.5 \pm 2.6$ & 0.0017 & $\leq 0.01$ & 3.55 \\
\hline $\mathrm{Fe}$ & $223 \pm 10$ & $255 \pm 27$ & 0.278 & $>0.05$ & 1.14 \\
\hline I & $1841 \pm 107$ & $71.8 \pm 10.1$ & 0.00000000001 & $\leq 0.01$ & 0.039 \\
\hline $\mathrm{K}$ & $6418 \pm 290$ & $10054 \pm 877$ & 0.00060 & $\leq 0.01$ & 1.57 \\
\hline $\mathrm{Li}$ & $0.0208 \pm 0.0022$ & $0.0314 \pm 0.0090$ & 0.265 & $>0.05$ & 1.51 \\
\hline $\mathrm{Mg}$ & $296 \pm 16$ & $478 \pm 42$ & 0.00043 & $\leq 0.01$ & 1.61 \\
\hline $\mathrm{Mn}$ & $1.28 \pm 0.07$ & $2.01 \pm 0.29$ & 0.024 & $\leq 0.01$ & 1.57 \\
\hline $\mathrm{Na}$ & $6928 \pm 175$ & $8576 \pm 531$ & 0.0069 & $\leq 0.01$ & 1.24 \\
\hline $\mathrm{P}$ & $4290 \pm 207$ & $10493 \pm 866$ & 0.0000054 & $\leq 0.01$ & 2.45 \\
\hline $\mathrm{S}$ & $8259 \pm 263$ & $9448 \pm 429$ & 0.027 & $\leq 0.01$ & 1.14 \\
\hline $\mathrm{Si}$ & $50.8 \pm 6.2$ & $143 \pm 42$ & 0.047 & $\leq 0.01$ & 2.81 \\
\hline $\mathrm{Sr}$ & $3.81 \pm 0.34$ & $6.26 \pm 1.59$ & 0.144 & $>0.05$ & 1.64 \\
\hline $\mathrm{V}$ & $0.102 \pm 0.005$ & $0.0904 \pm 0.0100$ & 0.305 & $>0.05$ & 0.89 \\
\hline $\mathrm{Zn}$ & $94.8 \pm 4.2$ & $96.9 \pm 12.6$ & 0.877 & $>0.05$ & 1.02 \\
\hline
\end{tabular}

El - element, M - arithmetic mean, SEM - standard error of mean, Statistically significant values are in bold.

In a general sense $\mathrm{Al}, \mathrm{B}, \mathrm{Cu}, \mathrm{Fe}, \mathrm{K}, \mathrm{Li}, \mathrm{Mg}$, $\mathrm{Mn}, \mathrm{Na}, \mathrm{P}, \mathrm{S}, \mathrm{Si}, \mathrm{V}$, and $\mathrm{Zn}$ contents found in the "normal" and "adjacent" groups of thyroid tissue samples were very similar (Table 3). However, in the "adjacent" group mean mass fractions of $\mathrm{Cl}$ and I were approximately 1.6 and 1.7 times, respectively, higher, while mean values of $\mathrm{Ba}, \mathrm{Ca}$ and $\mathrm{Sr}$ content were $55 \%$, $45 \%$, and $70 \%$, respectively, lower than in the "normal" group. Significant changes were found in tumor ChEs composition in comparison with thyroid tissue adjacent to tumor. In malignant tumor $\mathrm{Ca}, \mathrm{Cl}, \mathrm{Cu}$,
$\mathrm{K}$, and $\mathrm{Sr}$ contents were approximately $2.8,1.4,1.8$, 1.7, and 5.4 times, respectively, higher, while I content was 43 times lower than in "adjacent" group of tissue samples (Table 4).

Characteristically, elevated or reduced levels of ChEs observed in thyroid nodules are discussed in terms of their potential role in the initiation and promotion of these thyroid lesions. In other words, using the low or high levels of the ChEs in affected thyroid tissues researchers try to determine the role of 
Vladimir Zaichick., Saudi J Biomed Res, Jan, 2022; 7(1): 45-56

the deficiency or excess of each ChE in the etiology and pathogenesis of thyroid diseases. In our opinion, abnormal levels of many ChEs in TMNs could be and cause, and also effect of thyroid tissue transformation. From the results of such kind studies, it is not always possible to decide whether the measured decrease or increase in ChEs level in pathologically altered tissue is the reason for alterations or vice versa. According to our opinion, investigation of ChEs contents in thyroid tissue adjacent to malignant nodules and comparison obtained results with ChEs levels typical of "normal" thyroid gland may give additional useful information on the topic because these data show conditions of tissue in which TMNs were originated and developed.

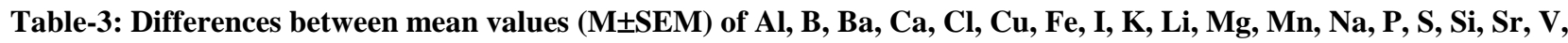
and $\mathrm{Zn}$ mass fraction ( $\mathrm{mg} / \mathrm{kg}$, dry mass basis) in normal thyroid and "intact" thyroid tissue adjacent to tumor

\begin{tabular}{|c|c|c|c|c|c|}
\hline \multirow[t]{2}{*}{ EI } & \multicolumn{4}{|l|}{ Thyroid tissue } & \multirow{2}{*}{$\begin{array}{l}\text { Ratio } \\
\text { Adjacent/Normal }\end{array}$} \\
\hline & $\begin{array}{l}\text { Normal } \\
\text { thyroid }\end{array}$ & $\begin{array}{l}\text { Cancer } \\
\text { (adjacent) }\end{array}$ & $\begin{array}{l}\text { Student's t-test } \\
p \leq\end{array}$ & $\begin{array}{l}\text { U-test } \\
p\end{array}$ & \\
\hline $\mathrm{Al}$ & $10.5 \pm 1.8$ & $19.4 \pm 5.6$ & 0.206 & $>0.05$ & 1.85 \\
\hline $\mathrm{B}$ & $0.476 \pm 0.058$ & $5.80 \pm 4.80$ & 0.348 & $>0.05$ & 12.2 \\
\hline $\mathrm{Ba}$ & $1.12 \pm 0.15$ & $0.50 \pm 0.16$ & 0.017 & $\leq 0.01$ & 0.45 \\
\hline $\mathrm{Ca}$ & $1682 \pm 106$ & $917 \pm 131$ & 0.000055 & $\leq 0.01$ & 0.55 \\
\hline $\mathrm{Cl}$ & $3400 \pm 174$ & $5339 \pm 581$ & 0.0054 & $\leq 0.01$ & 1.57 \\
\hline $\mathrm{Cu}$ & $4.08 \pm 0.14$ & $8.08 \pm 1.58$ & 0.084 & $>0.05$ & 1.98 \\
\hline $\mathrm{Fe}$ & $223 \pm 10$ & $256 \pm 26$ & 0.251 & $>0.05$ & 1.15 \\
\hline I & $1841 \pm 107$ & $3183 \pm 301$ & 0.00015 & $\leq \mathbf{0 . 0 1}$ & 1.73 \\
\hline $\mathrm{K}$ & $6418 \pm 290$ & $5847 \pm 661$ & 0.439 & $>0.05$ & 0.91 \\
\hline $\mathrm{Li}$ & $0.0208 \pm 0.0022$ & $0.0210 \pm 0.0100$ & 0.989 & $>0.05$ & 1.01 \\
\hline $\mathrm{Mg}$ & $296 \pm 16$ & $359 \pm 104$ & 0.558 & $>0.05$ & 1.21 \\
\hline $\mathrm{Mn}$ & $1.28 \pm 0.07$ & $1.77 \pm 0.40$ & 0.252 & $>0.05$ & 1.38 \\
\hline $\mathrm{Na}$ & $6928 \pm 175$ & $7726 \pm 630$ & 0.238 & $>0.05$ & 1.12 \\
\hline $\mathrm{P}$ & $4290 \pm 207$ & $9724 \pm 2796$ & 0.147 & $>0.05$ & 2.27 \\
\hline$S$ & $8259 \pm 263$ & $9725 \pm 999$ & 0.240 & $>0.05$ & 1.18 \\
\hline $\mathrm{Si}$ & $50.8 \pm 6.2$ & $77.3 \pm 28.1$ & 0.420 & $>0.05$ & 1.52 \\
\hline $\mathrm{Sr}$ & $3.81 \pm 0.34$ & $1.16 \pm 0.14$ & 0.000000002 & $\leq 0.01$ & 0.30 \\
\hline $\mathrm{V}$ & $0.102 \pm 0.005$ & $0.082 \pm 0.013$ & 0.220 & $>0.05$ & 0.80 \\
\hline $\mathrm{Zn}$ & $94.8 \pm 4.2$ & $111 \pm 11$ & 0.175 & $>0.05$ & 1.17 \\
\hline
\end{tabular}

$\mathrm{El}$ - element, $\mathrm{M}$ - arithmetic mean, SEM - standard error of mean, Statistically significant values are in bold.

Thus, from results obtained, it was possible to conclude that the common characteristics of TMNs in comparison with "normal" thyroid and visually "intact" thyroid tissue adjacent to malignant tumors were elevated levels of $\mathrm{Ca}, \mathrm{Cl}, \mathrm{Cu}$, and $\mathrm{K}$, as well as drastically reduced level of I (Tables 2 and 4). The last finding meant that thyroid tissue adjacent to malignant nodules kept the main function of thyroid gland, while malignantly transformed thyroid cells lost its capacity to accumulate I. Furthermore, the ChEs composition of thyroid tissue adjacent to tumor did not equal ChEs contents of "normal" thyroid (Table 3). For example, contents of such elements as mean mass fractions of $\mathrm{Cl}$ and I were approximately 1.6 and 1.7 times, respectively, higher (Table 3 ). From this it follows that the excessive accumulation of $\mathrm{Cl}$ and I by thyroid tissue is likely to precede the TMNs origination and development.

\section{Aluminum}

$\mathrm{Al}$ is the most widely distributed metal in the environment. Environmental media may be contaminated by $\mathrm{Al}$ from anthropogenic sources and through the weathering of rocks and minerals [56]. The trace element $\mathrm{Al}$ is not described as essential, because no biochemical function has been directly connected to it. Toxic actions of $\mathrm{Al}$ induce oxidative stress, immunologic alterations, genotoxicity, and other disorders, including cell membrane perturbation, apoptosis, necrosis and dysplasia [56]. Furthermore, it was shown in experimental and epidemiological studies that $\mathrm{Al}$ can affect thyroid iodide uptake and hormones secretion $[57,58]$. 
Vladimir Zaichick., Saudi J Biomed Res, Jan, 2022; 7(1): 45-56

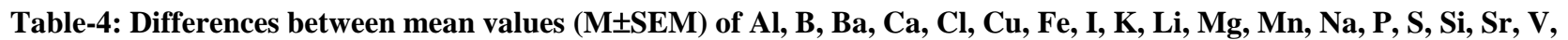
and $\mathrm{Zn}$ mass fraction ( $\mathrm{mg} / \mathrm{kg}$, dry mass basis) in thyroid cancer and "intact" thyroid tissue adjacent to tumor

\begin{tabular}{|c|c|c|c|c|c|}
\hline \multirow[t]{2}{*}{ El } & \multicolumn{4}{|l|}{ Thyroid tissue } & \multirow{2}{*}{$\begin{array}{l}\text { Ratio } \\
\text { Adjacent/Tumor }\end{array}$} \\
\hline & $\begin{array}{l}\text { Cancer } \\
\text { (adjacent) }\end{array}$ & $\begin{array}{l}\text { Cancer } \\
\text { (tumor) }\end{array}$ & $\begin{array}{l}\text { Student's t-test } \\
p \leq\end{array}$ & $\begin{array}{l}\text { U-test } \\
p\end{array}$ & \\
\hline $\mathrm{Al}$ & $19.4 \pm 5.6$ & $33.0 \pm 7.1$ & 0.157 & $>0.05$ & 1.70 \\
\hline $\mathrm{B}$ & $5.80 \pm 4.80$ & $2.21 \pm 0.52$ & 0.510 & $>0.05$ & 0.38 \\
\hline $\mathrm{Ba}$ & $0.50 \pm 0.16$ & $1.42 \pm 0.35$ & 0.028 & $\leq 0.01$ & 2.84 \\
\hline $\mathrm{Ca}$ & $917 \pm 131$ & $3013 \pm 699$ & 0.0085 & $\leq 0.01$ & 3.29 \\
\hline $\mathrm{Cl}$ & $5339 \pm 581$ & $7699 \pm 703$ & 0.015 & $\leq 0.01$ & 1.44 \\
\hline $\mathrm{Cu}$ & $8.08 \pm 1.58$ & $14.5 \pm 2.6$ & 0.051 & $\leq \mathbf{0 . 0 5}$ & 1.79 \\
\hline $\mathrm{Fe}$ & $256 \pm 26$ & $255 \pm 27$ & 0.982 & $>0.05$ & 1.00 \\
\hline I & $3183 \pm 301$ & $71.8 \pm 10.1$ & 0.00000000002 & $\leq 0.01$ & 0.023 \\
\hline $\mathrm{K}$ & $5847 \pm 661$ & $10054 \pm 877$ & 0.00053 & $\leq 0.01$ & 1.72 \\
\hline $\mathrm{Li}$ & $0.0210 \pm 0.0100$ & $0.0314 \pm 0.0090$ & 0.458 & $>0.05$ & 1.50 \\
\hline $\mathrm{Mg}$ & $359 \pm 104$ & $478 \pm 42$ & 0.301 & $>0.05$ & 1.33 \\
\hline $\mathrm{Mn}$ & $1.77 \pm 0.40$ & $2.01 \pm 0.29$ & 0.629 & $>0.05$ & 1.14 \\
\hline $\mathrm{Na}$ & $7726 \pm 630$ & $8576 \pm 531$ & 0.310 & $>0.05$ & 1.11 \\
\hline $\mathrm{P}$ & $9724 \pm 2796$ & $10493 \pm 866$ & 0.807 & $>0.05$ & 1.08 \\
\hline $\mathrm{S}$ & $9725 \pm 999$ & $9448 \pm 429$ & 0.811 & $>0.05$ & 0.97 \\
\hline $\mathrm{Si}$ & $77.3 \pm 28.1$ & $143 \pm 42$ & 0.214 & $>0.05$ & 1.85 \\
\hline $\mathrm{Sr}$ & $1.16 \pm 0.14$ & $6.26 \pm 1.59$ & 0.0040 & $\leq 0.01$ & 5.40 \\
\hline $\mathrm{V}$ & $0.082 \pm 0.013$ & $0.0904 \pm 0.0100$ & 0.620 & $>0.05$ & 1.11 \\
\hline $\mathrm{Zn}$ & $111 \pm 11$ & $96.9 \pm 12.6$ & 0.403 & $>0.05$ & 0.87 \\
\hline
\end{tabular}

El - element, M - arithmetic mean, SEM - standard error of mean, Statistically significant values are in bold.

Boron

Trace element $\mathrm{B}$ is known to influence the activity of many enzymes [59]. Numerous studies have demonstrated beneficial effects of B on human health, including anti-inflammatory stimulus - reduces levels of inflammatory biomarkers, such as high-sensitivity Creactive protein (hs-CRP) and tumor necrosis factor $\alpha$ $(\mathrm{TNF}-\alpha)$; as well as raises levels of antioxidant enzymes, such as superoxide dismutase (SOD), catalase, and glutathione peroxidase [60]. Why B content in TMNs is higher the normal level for thyroid and how an excess of B acts on thyroid gland are still to be cleared.

\section{Calsium, Strontium, and Barium}

It was reported that around $40 \%$ of TMNs have some type of calcification [61]. Thus, high Ca content in malignant tumor in comparison with thyroid tissue adjacent to tumor may be the result of TMNs calcification. Behavior of $\mathrm{Sr}$ and $\mathrm{Ba}$ are similar to $\mathrm{Ca}$, because these trace elements are in the same group of the periodic table. Reduced levels of $\mathrm{Ba}, \mathrm{Ca}$, and $\mathrm{Sr}$ content in thyroid tissue adjacent to tumor in comparison with "normal" thyroid may be explain by mobilization of these ChEs from adjacent tissue for tumor needs.

\section{Chlorine and sodium}

$\mathrm{Cl}$ and $\mathrm{Na}$ are ubiquitous, extracellular electrolytes essential to more than one metabolic pathway. In the body, $\mathrm{Cl}$ and $\mathrm{Na}$ mostly present as sodium chloride. Therefore, as usual, there is a correlation between $\mathrm{Na}$ and $\mathrm{Cl}$ contents in tissues and fluids of human body. Because $\mathrm{Cl}$ is halogen like $\mathrm{I}$, in the thyroid gland the biological behavior of chloride has to be similar to the biological behavior of iodide. The main source of natural $\mathrm{Cl}$ for human body is salt in food and chlorinated drinking water. Environment (air, water and food) polluted by artificial nonorganic $\mathrm{Cl}$-contained compounds, for example such as sodium chlorate $\left(\mathrm{NaClO}_{3}\right)$, and organic $\mathrm{Cl}$-contained compounds, for example such as polychlorinated biphenyls (PCBs) and dioxin, is other source. There is a clear association between using chlorinated drinking water, levels $\mathrm{NaClO}_{3}, \mathrm{PCBs}$ and dioxin in environment and thyroid disorders, including cancer [62-66]. Thus, on the one hand, the accumulated data suggest that $\mathrm{Cl}$ level in thyroid tissue might be responsible for TMNs development. However, on the other hand, it is well known that $\mathrm{Cl}$ and $\mathrm{Na}$ mass fractions in human tissue samples depend mainly on the extracellular water volume [67]. Tumors and adjacent to tumors thyroid tissues can be more vascularized than normal thyroid. Because blood is extracellular liquid, it is possible to speculate that more intensive vascularization could be the reason for elevated levels of $\mathrm{Cl}$ and $\mathrm{Na}$ in TMNs and adjacent tissue. If that is the case, the equilibrium between $\mathrm{Cl}$ and $\mathrm{Na}$ increases has to be, however, in comparison with "normal" thyroid the change of $\mathrm{Cl}$ level in tumors and adjacent tissue is significantly higher than change of $\mathrm{Na}$ level. Thus, it is possible to assume that an excessive accumulation of $\mathrm{Cl}$ in thyroid tissue is involved in TMNs etiology. Overall, the elevated levels of $\mathrm{Cl}$ in thyroid tissue could possibly be explored as risk factor of TMNs. 
Vladimir Zaichick., Saudi J Biomed Res, Jan, 2022; 7(1): 45-56

Coper

$\mathrm{Cu}$ is a ubiquitous element in the human body which plays many roles at different levels. Various $\mathrm{Cu}-$ enzymes (such as amine oxidase, ceruloplasmin, cytochrome-c oxidase, dopamine-monooxygenase, extracellular superoxide dismutase, lysyl oxidase, peptidylglycineamidating monoxygenase, $\mathrm{Cu} / \mathrm{Zn}$ superoxide dismutase, and tyrosinase) mediate the effects of $\mathrm{Cu}$ deficiency or excess. $\mathrm{Cu}$ excess can have severe negative impacts. $\mathrm{Cu}$ generates oxygen radicals and many investigators have hypothesized that excess copper might cause cellular injury via an oxidative pathway, giving rise to enhanced lipid peroxidation, thiol oxidation, and, ultimately, DNA damage [68-70]. Thus, $\mathrm{Cu}$ accumulation in thyroid parenchyma with age may be involved in oxidative stress, dwindling gland function, and increasing risk of goiter or cancer [25, 26, 31-34]. The significantly elevated level of $\mathrm{Cu}$ in thyroid malignant tumors and tissue adjacent to tumors, observed in the present study, supports this speculation. However, an overall comprehension of $\mathrm{Cu}$ homeostasis and physiology, which is not yet acquired, is mandatory to establish $\mathrm{Cu}$ exact role in the thyroid malignant tumors etiology and metabolism. Anyway, the accumulation of $\mathrm{Cu}$ in neoplastic thyroids could possibly be explored for diagnosis of TMNs.

\section{Iodine}

Nowadays it was well established that iodine deficiency or excess has severe consequences on human health and associated with the presence of TMNs [48,71-74]. In present study elevated level of I in thyroid tissue adjacent to malignant tumor and drastically reduced I mass fraction in cancerous tissue was found in comparison with "normal" thyroid.

Compared to other soft tissues, the human thyroid gland has higher levels of I, because this element plays an important role in its normal functions, through the production of thyroid hormones (thyroxin and triiodothyronine) which are essential for cellular oxidation, growth, reproduction, and the activity of the central and autonomic nervous system. As was shown in present study, malignant transformation is accompanied by a significant loss of tissue-specific functional features, which leads to a drastically reduction in I content associated with functional characteristics of the human thyroid tissue. Because the malignant part of gland stopped to produce thyroid hormones, the rest "intact" part of thyroid tries to compensate thyroid hormones deficiency and work more intensive than usual. The intensive work may explain elevated level of $\mathrm{I}$ in thyroid tissue adjacent to malignant tumor.

Drastically reduced level of I content in cancerous tissue could possibly be explored for differential diagnosis of benign and malignant thyroid nodules, because, as was found in our ealier studies, thyroid benign trasformation (goiter, thyroiditis, and adenoma) is accompanied by a little loss of I accumulation [42-45, 75-80].

\section{Potassium}

An uncontrollable cell proliferation characterize the malignant tumors. Therefore, morphological structures of TMNs differ from the structure of normal thyroid parenchyma. Because $\mathrm{K}$ is mainly an intracellular electrolyte, an elevated level of $\mathrm{K}$ content in cancerous tissue in comparison with "normal" and "adjacent" tissue might reflect increase of ratio "mass of transformed thyroid cell - mass of follicular colloid" in the malignant tumors. Nevertheless, the accumulation of $\mathrm{K}$ in neoplastic thyroids could possibly be explored for diagnosis of TMNs.

\section{Magnesium}

$\mathrm{Mg}$ is abundant in the human body. This element is essential for the functions of more than 300 enzymes (e.g. alkaline phosphatases, ATP-ases, phosphokinases, the oxidative phosphorylation pathway). It plays a crucial role in many cell functions such as energy metabolism, protein and DNA syntheses, and cytoskeleton activation. Moreover, $\mathrm{Mg}$ plays a central role in determining the clinical picture associated with thyroid disease [81]. Experimental data have shown that high doses of magnesium increase the activity of the thyroid gland [82]. Magnesium deficiency can influence bioavailability and tissue distribution of selenium which then appears diminished [83]. From these data, one can conclude that $\mathrm{Mg}$ is involved in the thyroid function. If so, significant reduction in $\mathrm{Mg}$ content cam be associate with TMNs, because malignant transformation is accompanied by a loss of thyroid-specific functional features. However, it is well known that malignant tumors have an usually higher $\mathrm{Mg}$ levels than do normal tissues [84-90], possibly caused by the "retention" of $\mathrm{Mg}$ by the tumor [91], as a result of the high $\mathrm{Mg}$ requirement of growing cells. In addition, cultured proliferating cells have long been known to contain more magnesium than quiescent cells, and experimental conditions that decreased magnesium availability affected cell proliferation rate [92]. Thus, the elevated levels of $\mathrm{Mg}$ in neoplastic thyroids could possibly be explored for diagnosis of TMNs.

\section{Manganese}

Trace element $\mathrm{Mn}$ is a cofactor for numerous enzymes, playing many functional roles in living organisms. The Mn-containing enzyme, manganese superoxide dismutase (Mn-SOD), is the principal antioxidant enzyme which neutralizes the toxic effects of reactive oxygen species. It has been speculated that Mn interferes with thyroid hormone binding, transport, and activity at the tissue level [93]. There is opinion that $\mathrm{Mn}$ deficiencies in humans are rare and humans maintain stable tissue levels of this trace element [94]. It was reported that intracellular $\mathrm{Mn}$ content was 
Vladimir Zaichick., Saudi J Biomed Res, Jan, 2022; 7(1): 45-56

positively correlated with manganese-containing superoxide dismutase (Mn-SOD), suggesting that the intracellular $\mathrm{Mn}$ level is associated with Mn-SOD activity [95]. However, an overall comprehension of $\mathrm{Mn}$ homeostasis and physiology, which is not yet acquired, is mandatory to establish $\mathrm{Mn}$ exact role in the TMNs etiology and metabolism. Anyway, the accumulation of $\mathrm{Mn}$ in neoplastic thyroids could possibly be explored for diagnosis of TMNs.

\section{Phosphorus}

$\mathrm{P}$ is necessary for several, various biological roles in the signal transduction of cells and energy exchange of human body. About $80 \%-90 \%$ of phosphorus is founded in teeth and bones in the form of hydroxyapatite. Calcium phosphates are one of the main constituents of mineral deposits in aortic wall and tissues [96]. Thus, the high $\mathrm{P}$ level in TMNs can be intimately linked with malignant tumor calcification [61].

\section{Sulfur}

Proteins contain between 3 and $6 \%$ of sulfur amino acids. Sulfur amino acids contribute substantially to the maintenance and integrity of the cellular systems by influencing the cellular redox state and the capacity to detoxify toxic compounds, free radicals and reactive oxygen species (ROS) [97]. ROS are generated during normal cellular activity and may exist in excess in some pathophysiological conditions, such as inflammation. Therefore exploring fundamental aspects of sulfur metabolism such as the antioxidant effects of sulfurcontaining amino acids [98] may help elucidate the mechanism by which the $\mathrm{S}$ content increases in TMNs. Thus, it might be assumed that the elevated $S$ level in thyroid with TMNs reflects an increase in concentration of ROS in malignant tissue.

\section{Silicon}

$\mathrm{Si}$ is the second most common $\mathrm{ChE}$ in the Earth's crust. This ChE is naturally present in foods as minerals: $\mathrm{Si}$ dioxide $\left(\mathrm{SiO}_{2}\right)$ and silicates. In potable water $\mathrm{Si}$ is mainly present as free orthosilicic acid $\left(\mathrm{H}_{4} \mathrm{SiO}_{4}\right)$ [99]. $\mathrm{Si}$ is mainly absorbed from the diet. For European population average dietary intake of Si from uncontaminated food and water was estimated as 20$50 \mathrm{mg} /$ day [100]. In such doze $\mathrm{Si}$ exerts beneficial effects on the human health, because as was shown in many in vitro and in vivo studies this element is involved in collagen synthesis, bone mineralization, structural integrity of nails, hair and skin [99]. However, over the last five decades $\mathrm{Si}$ compounds began widely use in medicine, for example, as oral supplements for improving osteoporosis, hair loss, nail, hair, and skin quality [101,102], as well as Sicontaining breast implants [103]. Silicones are included in cosmetic formulations such as hair conditioners, shampoos, and facial creams [102]. Si compounds are also of high importance in food and consumer products [104]. Due to favorable properties like colloidal and chemical stability, the possibility for a covalent surface modification, and a high specific surface area, the application cases for $\mathrm{Si}$ - contained particles and $\mathrm{Si}$ based materials have grown rapidly [104]. Thus, as a result of the above the $\mathrm{Si}$ intake constantly increases. There are many evidences for harmful effects of excessive $\mathrm{Si}$ accumulation in body tissues. For example, it was shown that reactive oxygen species (ROS) are generated on surface of $\mathrm{SiO}_{2}$ particles distributed in the interstitium [105]. In addition, $\mathrm{SiO}_{2}$ particles interact with macrophages, which secrete various inflammatory cytokines [106]. The elevated levels of ROS and inflammatory cytokines produce progressive inflammation [106]. Chronic inflammation induced by Si compounds can lead to allergic reaction, deficient humoral immune system, autoimmune diseases, fatal organ dysfunction, fibrosis, benign tumors, anaplastic large T cell lymphoma, and cancer [103-106].

\section{Limitations}

This study has several limitations. Firstly, analytical techniques employed in this study measure only nineteen $\mathrm{ChE}$ (Al, B, Ba, Ca, Cl, Cu, Fe, I, K, Li, $\mathrm{Mg}, \mathrm{Mn}, \mathrm{Na}, \mathrm{P}, \mathrm{S}, \mathrm{Si}, \mathrm{Sr}, \mathrm{V}$, and $\mathrm{Zn}$ ) mass fractions. Future studies should be directed toward using other analytical methods which will extend the list of $\mathrm{ChE}$ investigated in "normal" thyroid and in pathologically altered tissue. Secondly, the sample size of TMNs group was relatively small and prevented investigations of ChEs contents in this group using differentials like gender, histological types of TMNs, tumor functional activity, stage of disease, and dietary habits of patients with TMNs. Lastly, generalization of our results may be limited to Russian population. Despite these limitations, this study provides evidence on many ChEs level alteration in malignant tumor and thyroid tissue adjacent to tumor and shows the necessity to continue ChEs research of TMNs.

\section{CONCLUSION}

In this work, ChEs analysis was carried out in the tissue samples of TMNs using using a combination of non-destructive INAA-SLR and destructive ICPAES methods. It was shown that this combination is an adequate analytical tool for the non-destructive determination of $\mathrm{Al}, \mathrm{B}, \mathrm{Ba}, \mathrm{Ca}, \mathrm{Cl}, \mathrm{Cu}, \mathrm{Fe}, \mathrm{I}, \mathrm{K}, \mathrm{Li}, \mathrm{Mg}$, $\mathrm{Mn}, \mathrm{Na}, \mathrm{P}, \mathrm{S}, \mathrm{Si}, \mathrm{Sr}, \mathrm{V}$, and $\mathrm{Zn}$ content in the tissue samples of human thyroid in norm and pathology, including needle-biopsy specimens. It was observed that in malignant tissue the mass fractions of $\mathrm{Al}, \mathrm{B}, \mathrm{Ca}$, $\mathrm{Cl}, \mathrm{Cu}, \mathrm{K}, \mathrm{Mg}, \mathrm{Mn}, \mathrm{Na}, \mathrm{P}, \mathrm{S}$, and Si were 3.14, 4.64, $1.79,2.26,3.55,1.57,1.61,1.57,1.24,2.45,1.14$, and 2.81 times, respectively, higher whereas mass fraction of I was 25.6 times lower than in the normal thyroid. In a general sense $\mathrm{Al}, \mathrm{B}, \mathrm{Cu}, \mathrm{Fe}, \mathrm{K}, \mathrm{Li}, \mathrm{Mg}, \mathrm{Mn}, \mathrm{Na}, \mathrm{P}, \mathrm{S}$, $\mathrm{Si}, \mathrm{V}$, and $\mathrm{Zn}$ contents found in the "normal" and "adjacent" groups of thyroid tissue samples were very similar. However, in the "adjacent" group mean mass fractions of $\mathrm{Cl}$ and I were approximately 1.6 and 1.7 times, respectively, higher, while mean values of $\mathrm{Ba}, \mathrm{Ca}$ 
Vladimir Zaichick., Saudi J Biomed Res, Jan, 2022; 7(1): 45-56

and $\mathrm{Sr}$ content were $55 \%, 45 \%$, and $70 \%$, respectively, lower than in the "normal" group. Significant changes were found in tumor ChEs composition in comparison with thyroid tissue adjacent to tumor. In malignant tumor $\mathrm{Ca}, \mathrm{Cl}, \mathrm{Cu}, \mathrm{K}$, and $\mathrm{Sr}$ contents were approximately 2.8, 1.4, 1.8, 1.7, and 5.4 times, respectively, higher, while I content was 43 times lower than in "adjacent" group of tissue samples.

Thus, from results obtained, it was possible to conclude that the common characteristics of TMNs in comparison with "normal" thyroid and visually "intact" thyroid tissue adjacent to malignant tumors were elevated levels of $\mathrm{Ca}, \mathrm{Cl}, \mathrm{Cu}$, and $\mathrm{K}$, as well as drastically reduced level of I. The last finding meant that thyroid tissue adjacent to malignant nodules kept the main function of thyroid gland, while malignantly transformed thyroid cells lost its capacity to accumulate I. Furthermore, the ChEs composition of thyroid tissue adjacent to tumor did not equal ChEs contents of "normal" thyroid and, for example, contents of such elements as $\mathrm{Cl}$ and I were approximately 1.6 and 1.7 times, respectively, higher. From this it was supposed that the excessive accumulation of $\mathrm{Cl}$ and I by thyroid tissue probably precede the TMNs origination and development. It was also supposed that elevated levels of $\mathrm{Al}, \mathrm{B}, \mathrm{Ca}, \mathrm{Cl}, \mathrm{Cu}, \mathrm{K}, \mathrm{Mg}, \mathrm{Mn}, \mathrm{Na}, \mathrm{P}, \mathrm{S}$, and $\mathrm{Si}$, as well as drastically reduced level of me in cancerous tissue could possibly be explored for differential diagnosis of benign and malignant thyroid nodules

\section{ACKNOWLEDGEMENTS}

The author is extremely grateful to Profs. Vtyurin BM and Medvedev VS, Medical Radiological Research Center, Obninsk, as well as to Dr. Choporov $\mathrm{Yu}$, former Head of the Forensic Medicine Department of City Hospital, Obninsk, for supplying thyroid samples. The author is also grateful to Dr. Karandaschev V, Dr. Nosenko S, and Moskvina I, Institute of Microelectronics Technology and High Purity Materials, Chernogolovka, Russia, for their help in ICP-AES analysis.

\section{REFERENCES}

1. Laha D, Nilubol N, Boufraqech M. New therapies for advanced thyroid cancer. Front Endocrinol (Lausanne) 2020;11:82.

2. Buczyńska A, Sidorkiewicz I, Rogucki M, Siewko K, Adamska A, Kościuszko M, Maliszewska K, Kozłowska G, Szumowski P, Myśliwiec J, Krętowski A, Popławska-Kita A. Oxidative stress and radioiodine treatment of differentiated thyroid cancer. Sci Rep 2021;11:17126.

3. Prete A, Borges de Souza P, Censi S, Muzza M, Nucci N, Sponziello M. Update on Fundamental Mechanisms of Thyroid Cancer. Front Endocrinol (Lausanne) 2020;11:102.

4. Barrea L, Gallo M, Ruggeri RM, Di Giacinto P, Sesti F, Prinzi N, Adinolfi V, Barucca V, Renzelli V, Muscogiuri G, Colao A, Baldelli R. Nutritional status and follicular-derived thyroid cancer: An update. Crit Rev Food Sci Nutr 2021;61(1):25-59.

5. Zaichick V. Iodine excess and thyroid cancer. J Trace Elem Exp Med 1998;11(4):508-509.

6. Zaichick V., Iljina T. Dietary iodine supplementation effect on the rat thyroid ${ }^{131}$ I blastomogenic action. In: Die Bedentung der Mengen- und Spurenelemente. 18. Arbeitstangung. Jena: Friedrich-Schiller-Universität; 1998:294-306.

7. Kim K, Cho SW, Park YJ, Lee KE, Lee D-W, Park SK. Association between iodine intake, thyroid function, and papillary thyroid cancer: A case-control study. Endocrinol Metab (Seoul) 2021;36(4):790-799.

8. Vargas-Uricoechea P, Pinzón-Fernández MV, Bastidas-Sánchez BE, Jojoa-Tobar E, RamírezBejarano LE, Murillo-Palacios J. Iodine status in the colombian population and the impact of universal salt iodization: a double-edged sword? J Nutr Metab 2019;2019:6239243.

9. Stojsavljević A, Rovčanin B, Krstić D, BorkovićMitić S, Paunović I, Diklić A, Gavrović-Jankulović M, Manojlović D. Risk assessment of toxic and essential trace metals on the thyroid health at the tissue level: The significance of lead and selenium for colloid goiter disease. Expo Health 2019.

10. Fahim YA, Sharaf NE, Hasani IW, Ragab EA, Abdelhakim HK. Assessment of thyroid function and oxidative stress state in foundry workers exposed to lead. J Health Pollut 2020;10(27):200903.

11. Liu M, Song J, Jiang Y, Lin Y, Peng J, Liang H, Wang C, Jiang J, Liu X, Wei W, Peng J, Liu S, Li Y, $\mathrm{Xu} \mathrm{N}$, Zhou D, Zhang Q, Zhang J. A case-control study on the association of mineral elements exposure and thyroid tumor and goiter. Ecotoxicol Environ Saf 2021;208:111615.

12. Zaichick V. Medical elementology as a new scientific discipline. J Radioanal Nucl Chem 2006;269:303-309.

13. Moncayo R, Moncayo H. A post-publication analysis of the idealized upper reference value of $2.5 \mathrm{mIU} / \mathrm{L}$ for TSH: Time to support the thyroid axis with magnesium and iron especially in the setting of reproduction medicine. BBA Clin 2017;7:115-119.

14. Beyersmann D, Hartwig A. Carcinogenic metal compounds: recent insight into molecular and cellular mechanisms. Arch Toxicol 2008;82(8):493-512.

15. Martinez-Zamudio R, Ha HC. Environmental epigenetics in metal exposure. Epigenetics 2011;6(7):820-827.

16. Zaĭchik V, Raibukhin YuS, Melnik AD, Cherkashin VI. Neutron-activation analysis in the study of the behavior of iodine in the organism. Med Radiol (Mosk) 1970;15(1):33-36.

17. Zaĭchik V, Matveenko EG, Vtiurin BM, Medvedev VS. Intrathyroid iodine in the diagnosis of thyroid cancer. Vopr Onkol 1982;28(3):18-24.

18. Zaichick V, Tsyb AF, Vtyurin BM. Trace elements and thyroid cancer. Analyst 1995;120(3):817-821.

19. Zaichick V, Choporov YuYa. Determination of the natural level of human intra-thyroid iodine by instrumental neutron activation analysis. J Radioanal Nucl Chem 1996;207(1):153-161.

20. Zaichick V. In vivo and in vitro application of energydispersive XRF in clinical investigations: experience 
Vladimir Zaichick., Saudi J Biomed Res, Jan, 2022; 7(1): 45-56

and the future. $\mathrm{J}$ Trace Elem Exp Med 1998;11(4):509-510.

21. Zaichick V, Zaichick S. Energy-dispersive X-ray fluorescence of iodine in thyroid puncture biopsy specimens. J Trace Microprobe Tech 1999;17(2):219232.

22. Zaichick V. Relevance of, and potentiality for in vivo intrathyroidal iodine determination. Ann N Y Acad Sci 2000;904:630-632.

23. Zaichick V, Zaichick S. Normal human intrathyroidal iodine. Sci Total Environ 1997;206(1):39-56.

24. Zaichick V. Human intrathyroidal iodine in health and non-thyroidal disease. In: New aspects of trace element research (Eds: M.Abdulla, M.Bost, S.Gamon, P.Arnaud, G.Chazot). London: Smith-Gordon; and Tokyo: Nishimura; 1999:114-119.

25. Zaichick V, Zaichick S. Age-related changes of some trace element contents in intact thyroid of females investigated by energy dispersive X-ray fluorescent analysis. Trends Geriatr Healthc 2017,1(1):31-38.

26. Zaichick V, Zaichick S. Age-related changes of some trace element contents in intact thyroid of males investigated by energy dispersive X-ray fluorescent analysis. MOJ Gerontol Ger 2017;1(5):00028.

27. Zaichick V, Zaichick S. Age-related changes of $\mathrm{Br}$, $\mathrm{Ca}, \mathrm{Cl}, \mathrm{I}, \mathrm{K}, \mathrm{Mg}, \mathrm{Mn}$, and $\mathrm{Na}$ contents in intact thyroid of females investigated by neutron activation analysis. Curr Updates Aging 2017;1:5.1.

28. Zaichick V, Zaichick S. Age-related changes of $\mathrm{Br}$, $\mathrm{Ca}, \mathrm{Cl}, \mathrm{I}, \mathrm{K}, \mathrm{Mg}, \mathrm{Mn}$, and $\mathrm{Na}$ contents in intact thyroid of males investigated by neutron activation analysis. J Aging Age Relat Dis 2017;1(1):1002.

29. Zaichick V, Zaichick S. Age-related changes of Ag, $\mathrm{Co}, \mathrm{Cr}, \mathrm{Fe}, \mathrm{Hg}, \mathrm{Rb}, \mathrm{Sb}, \mathrm{Sc}, \mathrm{Se}$, and $\mathrm{Zn}$ contents in intact thyroid of females investigated by neutron activation analysis. J Gerontol Geriatr Med 2017;3:015.

30. Zaichick V, Zaichick S. Age-related changes of Ag, $\mathrm{Co}, \mathrm{Cr}, \mathrm{Fe}, \mathrm{Hg}, \mathrm{Rb}, \mathrm{Sb}, \mathrm{Sc}, \mathrm{Se}$, and $\mathrm{Zn}$ contents in intact thyroid of males investigated by neutron activation analysis. Curr Trends Biomedical Eng Biosci 2017;4(4):555644.

31. Zaichick V, Zaichick S. Effect of age on chemical element contents in female thyroid investigated by some nuclear analytical methods. MicroMedicine 2018;6(1):47-61.

32. Zaichick V, Zaichick S. Neutron activation and X-ray fluorescent analysis in study of association between age and chemical element contents in thyroid of males. Op Acc J Bio Eng Bio Sci 2018;2(4):202-212.

33. Zaichick V, Zaichick S. Variation with age of chemical element contents in females' thyroids investigated by neutron activation analysis and inductively coupled plasma atomic emission spectrometry. J Biochem Analyt Stud 2018;3(1):1-10.

34. Zaichick V, Zaichick S. Association between age and twenty chemical element contents in intact thyroid of males. SM Gerontol Geriatr Res 2018;2(1):1014.

35. Zaichick V, Zaichick S. Associations between age and 50 trace element contents and relationships in intact thyroid of males. Aging Clin Exp Res 2018;30(9):1059-1070.
36. Zaichick V, Zaichick S. Possible role of inadequate quantities of intra-thyroidal bromine, rubidium and zinc in the etiology of female subclinical hypothyroidism. EC Gynaecology 2018;7(3):107-115.

37. Zaichick V, Zaichick S. Possible role of inadequate quantities of intra-thyroidal bromine, calcium and magnesium in the etiology of female subclinical hypothyroidism. Int Gyn and Women's Health 2018;1(3):IGWHC.MS.ID.000113.

38. Zaichick V, Zaichick S. Possible role of inadequate quantities of intra-thyroidal cobalt, rubidium and zinc in the etiology of female subclinical hypothyroidism. Womens Health Sci J 2018;2(1):000108.

39. Zaichick V, Zaichick S. Association between female subclinical hypothyroidism and inadequate quantities of some intra-thyroidal chemical elements investigated by X-ray fluorescence and neutron activation analysis. Gynaecology and Perinatology 2018;2(4):340-355.

40. Zaichick V, Zaichick S. Investigation of association between the high risk of female subclinical hypothyroidism and inadequate quantities of twenty intra-thyroidal chemical elements. Clin Res: Gynecol Obstet 2018;1(1):1-18.

41. Zaichick V, Zaichick S. Investigation of association between the high risk of female subclinical hypothyroidism and inadequate quantities of intrathyroidal trace elements using neutron activation and inductively coupled plasma mass spectrometry. Acta Scientific Medical Sciences 2018;2(9):23-37.

42. Zaichick V. Determination of twenty chemical element contents in macro- and micro-follicular colloid goiter using neutron activation analysis and inductively coupled plasma atomic emission spectrometry. International Journal of Medical and All Body Health Research 2021;2(2):5-18.

43. Zaichick V. Comparison of twenty chemical element contents in normal thyroid tissue and hypertrophic thyroid tissue. Universal Journal of Pharmaceutical Research 2021;6(4):32-42.

44. Zaichick V. Evaluation of twenty chemical element contents in thyroid adenomas using neutron activation analysis and inductively coupled plasma atomic emission spectrometry. World Journal of Advanced Research and Reviews 2021;11(03):242-257.

45. Zaichick V. Are there any differences between chemical element contents of goitrous and adenomatous thyroid? Journal of Medical Research and Health Sciences 2021;4(11):1576-1587.

46. Zaichick V, Zaichick S. Instrumental effect on the contamination of biomedical samples in the course of sampling. The Journal of Analytical Chemistry 1996;51(12):1200-1205.

47. Zaichick V, Zaichick S. A search for losses of chemical elements during freeze-drying of biological materials. J Radioanal Nucl Chem 1997;218(2):249253.

48. Zaichick $\mathrm{S}$, Zaichick V. INAA application in the age dynamics assessment of $\mathrm{Br}, \mathrm{Ca}, \mathrm{Cl}, \mathrm{K}, \mathrm{Mg}, \mathrm{Mn}$, and $\mathrm{Na}$ content in the normal human prostate. J Radioanal Nucl Chem 2011;288:197-202.

49. Zaichick V, Zaichick S. The effect of age on Br, Ca, $\mathrm{Cl}, \mathrm{K}, \mathrm{Mg}, \mathrm{Mn}$, and $\mathrm{Na}$ mass fraction in pediatric and 
Vladimir Zaichick., Saudi J Biomed Res, Jan, 2022; 7(1): 45-56

young adult prostate glands investigated by neutron activation analysis. J Appl Radiat Isot 2013;82:145151

50. Zaichick V, Nosenko S, Moskvina I. The effect of age on 12 chemical element contents in intact prostate of adult men investigated by inductively coupled plasma atomic emission spectrometry. Biol Trace Elem Res 2012;147:49-58.

51. Zaichick V, Zaichick S. NAA-SLR and ICP-AES Application in the assessment of mass fraction of 19 chemical elements in pediatric and young adult prostate glands. Biol Trace Elem Res 2013;156:357366.

52. Zaichick V, Zaichick S. Determination of trace elements in adults and geriatric prostate combining neutron activation with inductively coupled plasma atomic emission spectrometry. Open Journal of Biochemistry 2014;1(2):16-33.

53. Zaichick S, Zaichick V. The effect of age and gender on 37 chemical element contents in scalp hair of healthy humans. Biol Trace Elem Res 2010;134(1):41-54.

54. Zaichick V. Applications of synthetic reference materials in the medical Radiological Research Centre. Fresenius J Anal Chem 1995;352:219-223.

55. Korelo AM, Zaichick V. Software to optimize the multielement INAA of medical and environmental samples. In: Activation Analysis in Environment Protection. Dubna, Russia: Joint Institute for Nuclear Research; 1993:326-332.

56. Igbokwe IO, Igwenagu E, Igbokwe NA. Aluminium toxicosis: a review of toxic actions and effects. Interdiscip Toxicol 2019;12(2):45-70.

57. Orihuela D. Aluminium effects on thyroid gland function: iodide uptake, hormone biosynthesis and secretion. J Inorg Biochem 2011;105(11):1464-1468.

58. Benvenga S, Elia G, Ragusa F, Paparo SR, Sturniolo MM, Ferrari SM, Antonelli A, Fallahi P. Endocrine disruptors and thyroid autoimmunity. Best Pract Res Clin Endocrinol Metab 2020;34(1):101377.

59. Naghii MR, Mofid M, Asgari AR, Hedayati M, Daneshpour MS. Comparative effects of daily and weekly boron supplementation on plasma steroid hormones and proinflammatory cytokines. J Trace Elem Med Biol 2011;25:54-58.

60. Pizzorno L. Nothing boring about boron. Integr Med (Encinitas) 2015;14:35-48.

61. Ferreira LB, Gimba E, Vinagre J, Sobrinho-Simões M, Soares P. Molecular aspects of thyroid calcification. Int J Mol Sci 2020;21(20):7718.

62. Leko MB, Gunjača I, Pleić $N$, Zemunik $T$. Environmental Factors Affecting Thyroid-Stimulating Hormone and Thyroid Hormone Levels. Int J Mol Sci 2021;22(12):6521.

63. Schwartz GG, Klug MG. Thyroid Cancer Incidence Rates in North Dakota are Associated with Land and Water Use. Int $\mathbf{J}$ Environ Res Public Health. 2019;16(20):3805.

64. National Toxicology Program. Toxicology and carcinogenesis studies of sodium chlorate (Cas No. 7775-09-9) in $\mathrm{F} 344 / \mathrm{N}$ rats and $\mathrm{B} 6 \mathrm{C} 3 \mathrm{~F} 1$ mice (drinking water studies). Natl Toxicol Program Tech Rep Ser 2005;517:1-255.
65. Parazzini F, Esposito G, Tozzi L, Tozzi S. Epidemiology of endometriosis and its comorbidities. Eur J Obstet Gynecol Reprod Biol 2017;209:3-7.

66. Sokal A, Jarmakiewicz-Czaja S, Tabarkiewicz J, Filip R. Dietary Intake of Endocrine Disrupting Substances Presents in Environment and Their Impact on Thyroid Function. Nutrients 2021;13(3):867.

67. Zaichick V. X-ray fluorescence analysis of bromine for the estimation of extracellular water. J Appl Radiat Isot. 1998;49(12):1165-1169.

68. Li Y, Trush MA. DNA damage resulting from the oxidation of hydroquinone by copper: role for a $\mathrm{Cu}(\mathrm{II}) / \mathrm{Cu}(\mathrm{I})$ redox cycle and reactive oxygen generation. Carcinogenesis 1993;14(7):1303-1311.

69. Becker TW, Krieger G, Witte I. DNA single and double strand breaks induced by aliphatic and aromatic aldehydes in combination with copper (II). Free Radic Res 1996;24(5):325-332.

70. Glass GA, Stark AA. Promotion of glutathionegamma-glutamyl transpeptidase-dependent lipid peroxidation by copper and ceruloplasmin: the requirement for iron and the effects of antioxidants and antioxidant enzymes. Environ Mol Mutagen 1997;29(1):73-80.

71. Kant R, Davis A, Verma V. Thyroid nodules: Advances in evaluation and management. Am Fam Physician 2020;102(5):298-304.

72. Leung AM, Braverman LE. Consequences of excess iodine. Nat Rev Endocrinol 2014;10(3):136-142.

73. Lee J-H, Hwang Y, Song R-Y, Yi JW, Yu HW, Kim S-J, Chai YJ, ChoiJY, Lee KE, Park SK. Relationship between iodine levels and papillary thyroid carcinoma: A systematic review and meta-analysis. Head Neck 2017;39(8):1711-1718.

74. Aakre I, Evensen LT, Kjellevold M, Dahl L, Henjum S, Alexander J, Madsen L, Markhus MW. Iodine status and thyroid function in a group of seaweed consumers in Norway. Nutrients 2020;12(11):3483.

75. Zaichick V. Evaluation of trace elements in Riedel's Struma using energy dispersive X-ray fluorescence analysis. International Journal of Radiology Sciences 2021;3(1):30-34.

76. Zaichick V. Evaluation of thyroid trace elements in Hashimoto's thyroiditis using method of X-ray fluorescence. International Journal of Integrated Medical Research 2021;8(4):1-9.

77. Zaichick V. Comparison between Bromine, Calcium, Chlorine, Iodine, Potassium, Magnesium, Manganese, and Sodium Contents in Normal Thyroid and Riedel's Struma. Journal of Biotechnology \& Bioinformatics Research 2021;3(4):1-6.

78. Zaichick V. Comparison between Bromine, Calcium, Chlorine, Iodine, Potassium, Magnesium, Manganese, and Sodium Contents in Normal Thyroid and Thyroid with Hashimoto's thyroiditis. J Clin Res Oncol 2021;4(1):21-27.

79. Zaichick V. Comparison of Nineteen Chemical Element Contents in Normal Thyroid and Thyroid with Riedel's Struma. Journal of Medical Research and Health Sciences 2021;4 (11): 1529-1538.

80. Zaichick V. Evaluation of twenty chemical elements in thyroid with Hashimoto's thyroiditis using X-ray fluorescent and neutron activation analysis. Journal of 
Vladimir Zaichick., Saudi J Biomed Res, Jan, 2022; 7(1): 45-56

Medical Research and Health Sciences
2021;2(10):1500-1510.

81. Moncayo R, Moncayo H. Applying a systems approach to thyroid physiology: Looking at the whole with a mitochondrial perspective instead of judging single TSH values or why we should know more about mitochondria to understand metabolism. BBA Clin 2017;7:127-140.

82. Chandra A.K. Effects of magnesium on cytomorphology and enzyme activities in thyroid of rats. Indian J Exp Biol 2014;52:787-792.

83. Jiménez A. Changes in bioavailability and tissue distribution of selenium caused by magnesium deficiency in rats. J Am Coll Nutr 1997;16:175-180.

84. Durlach J, Bara M, Guiet-Bara A, Collery P. Relationship between magnesium, cancer and carcinogenic or anticancer metals. Anticancer Res 1986;6:1353-1361.

85. Mulay IL, Roy R, Knox BE, Suhr NH, Delaney WE. Trace-metal analysis of cancerous and non-cancerous human tissues. J Natl Cancer Inst 1971;47:1-13.

86. Anghileri LJ, Miller ES, Robinette J, Prasad KN, Lagerborg VA. Calcium metabolism in tumors. II. Calcium, magnesium and phosphorus in human and animal tumors. Oncology 1971;25:193-209.

87. Digiesi V, Bandinelli R, Bisceglie P, Santoro E. Magnesium in tumoral tissues, in the muscle and serum of subjects suffering from neoplasia. Biochem Med 1983;29:360-363.

88. Szmeja Z, Koenczewska H. Red blood cell, serum and tissue magnesium levels in subjects with laryngeal carcinoma. J Otorhinolaryngol Relat Spec 1983;45:102-107.

89. Ranade SS, Panday VK. Major metals in human cancer: calcium, magnesium, sodium and potassium. Sci Total Environm 1985;41:79-89.

90. Taylor JS, Vigneron DB, Murphy-Boesch J Nelson S., Kessler HB, Coia L, Curran W, Brown TR.. Free magnesium levels in normal human brain and brain tumors: 31P chemical-shift imaging measurements at 1.5 T. Proc Natl Acad Sci USA 1991;88:6810-6814.

91. Collery P, Anghileri LJ, Coudoux P, Durlach J. Magnesium and cancer: Clinical data. Magnesium Bull 1981;3:11-20.

92. Wolf FI, Cittadini ARM, Maier AM. Magnesium and tumors: Ally or foe? Cancer Treatment Reviews 2009;35(4):378-382.

93. Soldin OP, Aschner M. Effects of manganese on thyroid hormone homeostasis. Neurotoxicology 2007;28:951-956.
94. Aschner JL, Aschner M. Nutritional aspects of manganese homeostasis. Mol Aspects Med 2005;26:353-362.

95. Hasegawa S, Koshikawa M, Takahashi I, Hachiya M, Furukawa T, Akashi M, Yoshida S, Saga T. Alterations in manganese, copper, and zinc contents, and intracellular status of the metal-containing superoxide dismutase in human mesothelioma cells. J Trace Elem Med Biol 2008;22:248-255.

96. Kowalska J, Gajda M, Kwiatek WM, Franczyk-Zarów M, Kostogrys RB, Chłopicki S, Sandt C, Dumas P. Chemical composition of atherosclerotic plaques of apoE/LDLR-double knockout mice by synchrotron radiation FTIR microspectroscopy. Acta Physica Polonica 2012;121:555-560.

97. Townsend DM, Tew KD, Tapiero H. Sulfur containing amino acids and human disease. Biomed Pharmacother 2004;58:47-55.

98. Atmaca G. Antioxidant effects of sulfur-containing amino acids. Yonsei Med J 2004;45:776-788.

99. Boqué N, Valls RM, Pedret A, Arola L, Puiggrós F, Solà R. Relative absorption of silicon from different formulations of dietary supplements: a pilot randomized, double-blind, crossover post-prandial study. Sci Rep 2021;11:16479

100.Pennington JAT. Silicon in foods and diets. Food Addit. Contam 1991;8:97-118.

101.Rondanelli M, Faliva MA, Peroni G, Gasparri C, Perna S, Riva A, Petrangolini G, Tartara A. Silicon: A neglected micronutrient essential for bone health. Exp Biol Med (Maywood) 2021;246(13):1500-1511.

102. Michalak M, Pierzak M, Kręcisz B, Suliga E. Bioactive Compounds for Skin Health: A Review. Nutrients. 2021;13(1):203.

103.Colaris MJL, de Boer M, van der Hulst RR, Tervaert JWC. Two hundreds cases of ASIA syndrome following silicone implants: a comparative study of 30 years and a review of current literature. Immunol Res 2017;65(1):120-128.

104.Kersting M, Olejnik M, Rosenkranz N, Loza K, Breisch M, Rostek A, Westphal G, Bünger J, Ziegler N, Ludwig A, Köller M, Sengstock C, Epple M. Subtoxic cell responses to silica particles with different size and shape. Sci Rep 2020;10(1):21591.

105.Fubini B, Hubbard A. Reactive oxygen species (ROS) and reactive nitrogen species (RNS) generation by silica in inflammation and fibrosis. Free Radic Biol Med 2003;34(12):1507-1516.

106. Kawasaki H. A mechanistic review of silica-induced inhalation toxicity. Inhal Toxicol 2015;27(8):363-377. 